\title{
Recommendations for the assessment and management of cough in children
}

\author{
M D Shields, ${ }^{1}$ A Bush, ${ }^{2}$ M L Everard, ${ }^{3}$ S McKenzie, ${ }^{4}$ R Primhak, ${ }^{3}$ on behalf of the British \\ Thoracic Society Cough Guideline Group
}

${ }^{1}$ Department of Child Health, Queen's University of Belfast, Clinical Institute, Belfast, UK; ${ }^{2}$ Royal Brompton Hospital, London, UK; ${ }^{3}$ Department of Paediatrics, Sheffield Children's Hospital, Sheffield, UK; ${ }^{4}$ Queen Elizabeth Children's Services, The Royal London Hospital, London, UK

Correspondence to:

Dr M D Shields, Department of Child Health, Queen's University of Belfast, Clinical Institute, Grosvenor Road, Belfast BT12 6BJ, UK; m.shields@qub.ac.uk

Received 5 January 2007 Accepted 13 September 2007 Published Online First 28 September 2007

\section{INTRODUCTION}

All children experience head colds and many consult their doctor because of associated coughing. ${ }^{1}$ Cough with colds remedies are among the most commonly used medications in children in Western societies, despite evidence suggesting ineffectiveness of medication to treat cough as a symptom. The aetiology of coughing in children will cover a wide spectrum of respiratory disorders, and finding and treating the underlying cause is important.

Community-based surveys show that parentalreported cough as an isolated symptom has a high prevalence. ${ }^{23}$ Reported cough without colds has a prevalence of $28 \%$ in boys and $30 \%$ in girls. ${ }^{4}$

The recognised underdiagnosis of asthma led to the importance of cough as a symptom being stressed. However, there is increasing evidence that children are inappropriately treated for asthma based on cough as the sole symptom. ${ }^{5}{ }^{6}$

Coughing in children can be distressing and has a major impact on a child's sleep, school performance and ability to play. It may similarly disturb other family members' sleep and be disruptive for school teachers. Considerable parental anxiety is generated in families with a child with problem coughing. ${ }^{\text {8 }}$

The reported severity of a child's cough may relate to how it affects parents and teachers. Recent evidence has highlighted that parental reporting of the frequency and severity of a child's cough is unreliable compared with objective measures, and this is especially true for nocturnal cough. Indeed, it has been suggested that cough as reported in surveys and as a clinical trial outcome should either not be used or be interpreted with caution. ${ }^{9-12}$ This limits the certainty that can be placed on most of the published literature that has not used objective cough measurements.

\section{The need and purpose of BTS recommendations on the management of cough}

These guidelines are needed because childhood coughing is a common problem that generates much anxiety, has numerous different causes and is often wrongly diagnosed and inappropriately treated. Differences between childhood and adult cough suggest the need for separate guidelines. The "big three" causes of adult chronic cough (cough variant asthma, postnasal drip and gastrooesophageal reflux) are not necessarily valid for children. ${ }^{13}$

The aim is to produce guidelines that are relevant to the clinical management of cough in children up to 12 years of age without known lung disease in primary and secondary care. Both adult and childhood conditions and treatments will need to be considered when dealing with teenagers. No attempt has been made to provide a comprehensive list of all causes of coughing.

These guidelines cover acute, chronic and recurrent coughing. We have used the approach that an attempt should be made to arrive at a specific diagnosis for cause of cough (specific cough). We have covered the commonly encountered situation of a child who does not appear to have a specific pointer to a cause or to have significant underlying serious disease but has problem cough (non-specific isolated cough).

\section{Methodology for generation of the guidelines}

There is currently a lack of evidence on which to make evidence-based statements for the diagnosis, investigation and treatments included in this guideline. Most of the features of a cough and investigations have not been formally evaluated for their predictive value in the diagnosis of a specific condition. In the Cochrane Library database, three recent systematic reviews of treatment of prolonged non-specific cough in children (inhaled anticholinergics, theophyllines and cromones) found no eligible randomised controlled trials (RCTs) and, in a further review (treatment of gastro-oesophageal reflux), three paediatric studies were found but none could be included in the meta-analysis. ${ }^{14-17}$

In order to make opinion and consensus-based statements based on the known literature that would be useful the following methodology was used.

\section{Step 1}

MDS performed a database literature search (Medline, Embase, Cochrane Library and Google Scholar) initially using the terms "cough" AND "child". Exclusions included non-English language papers and papers on pertussis vaccine development. Also excluded were papers on specific diseases including asthma, cystic fibrosis and pneumonia for which management guidelines have already been published. Abstracts of papers were then reviewed and relevant papers obtained. The relevant studies to the UK population were largely performed in Europe, North America, Australia, New Zealand and South Africa.

Specific searches of the databases were subsequently made adding the terms "gastroesophageal reflux", "cough variant asthma", "isolated" OR 
"non-specific cough" AND "randomised controlled trial" OR "placebo".

\section{Step 2}

MDS produced a framework document.

\section{Step 3}

The framework document was sent to the other team members (AB, SMcK, ME, RP) who modified the document and added their opinions until consensus was obtained.

\section{Step 4}

General practitioners (VMcG, TC and NW [GP trainee]) and paediatricians (NK, DO'D [trainee] and JH [trainee]) provided further comments on improving the usefulness of the guidelines.

\section{Terms used in this guideline \\ Cough}

For the purposes of this document, the following definition is used: "Cough is a forced expulsive manoeuvre, usually against a closed glottis and which is associated with a characteristic sound".

\section{Acute cough}

A recent onset of cough lasting $<3$ weeks.

\section{Chronic cough}

A cough lasting $>8$ weeks.

The main reason to classify cough on this time basis is that 34 weeks allows most simple infective causes of cough to have resolved and identifies those children with chronic cough that might require further investigations.

\section{Prolonged acute cough}

Clearly there is a "grey" area between acute and chronic cough, sometimes called "subacute cough". ${ }^{18}$ An example of such a situation would be a child with pertussis or postviral cough whose cough may be slowly resolving over a 3-8-week period. If a cough is resolving, an additional period of time may be required to elapse before performing further investigations. Most acute coughs associated with upper respiratory infections should be abating in the second and third week. However, if the

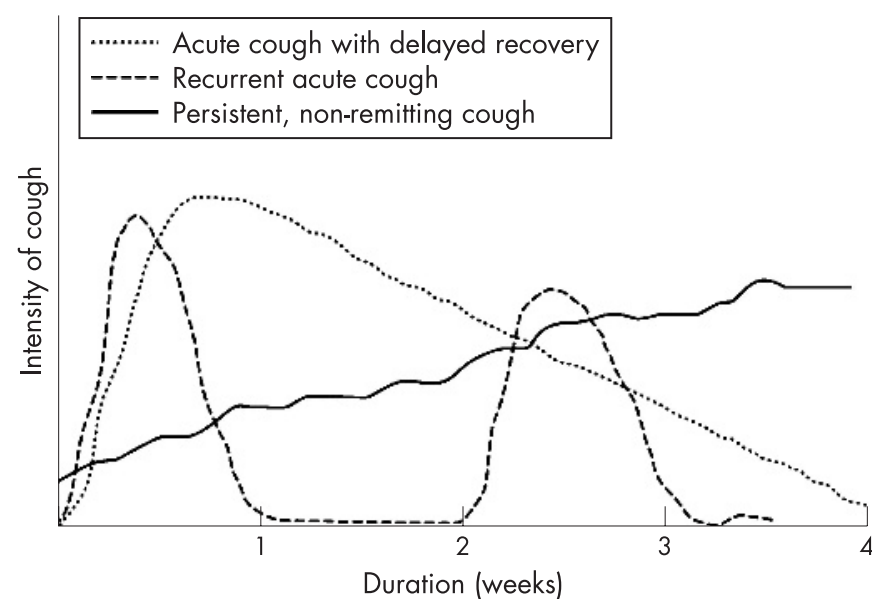

Figure 1 Illustration of how patterns of cough intensity vary over time. Reproduced with permission of the publishers from Marais et $a{ }^{21}$. cough is not waning by the third week and is becoming more severe in frequency and intensity ("relentlessly progressive"), earlier investigations may be warranted (see table 2).

\section{Recurrent cough}

A recurrent cough without a cold is taken as repeated ( $\geqslant 2 /$ year) cough episodes, apart from those associated with head colds, that each last more than 7-14 days. ${ }^{19}{ }^{20}$ If the periods of resolution are short, frequently recurrent cough will be difficult to distinguish from persistent chronic cough.

\section{Postviral cough}

Postviral cough is a cough originally starting with an upper respiratory tract infection but lasting $>3$ weeks.

\section{Specific cough}

A specific cough is one in which there is a clearly identifiable cause.

\section{Non-specific isolated cough}

The term "non-specific isolated cough" has been used to describe children who typically have a persistent dry cough, no other respiratory symptoms (isolated cough), are otherwise well with no signs of chronic lung disease and have a normal chest radiograph.

Figure 1 illustrates the types of cough intensity over time. ${ }^{21}$

\section{SUMMARY OF GUIDELINES FOR COUGH IN CHILDREN \\ Acute cough (fig 2) \\ Diagnosis}

- The majority of children with acute cough have a viral respiratory tract infection.

- An attempt should be made to arrive at a specific clinical diagnosis (see table 1).

- The absence of fever, tachypnoea and chest signs appear to be most useful for ruling out future complications in children with cough in primary care.

\section{Investigations}

- Most children with cough due to a simple upper respiratory tract infection will not need any investigations.

- Children in whom an inhaled foreign body is a likely cause of cough should undergo urgent bronchoscopy.

- A chest radiograph should be considered in the presence of lower respiratory tract signs, relentlessly progressive cough, haemoptysis or features of an undiagnosed chronic respiratory disorder (see table 2).

\section{Treatments}

- Over-the-counter medications are as effective as placebo for acute cough with head colds in children.

- Bronchodilators are not effective for acute cough in nonasthmatic children.

- Antibiotics are generally not effective or recommended for treating acute coughs caused by simple "head colds".

- Macrolide antibiotics should be given early (first 1-2 weeks) to children with pertussis.

- Antihistamines and intranasal steroids are beneficial for children with an allergic cough in the pollen season. 
Figure 2 A simplified overview of the assessment and management of the common causes of acute cough $<3$ weeks.

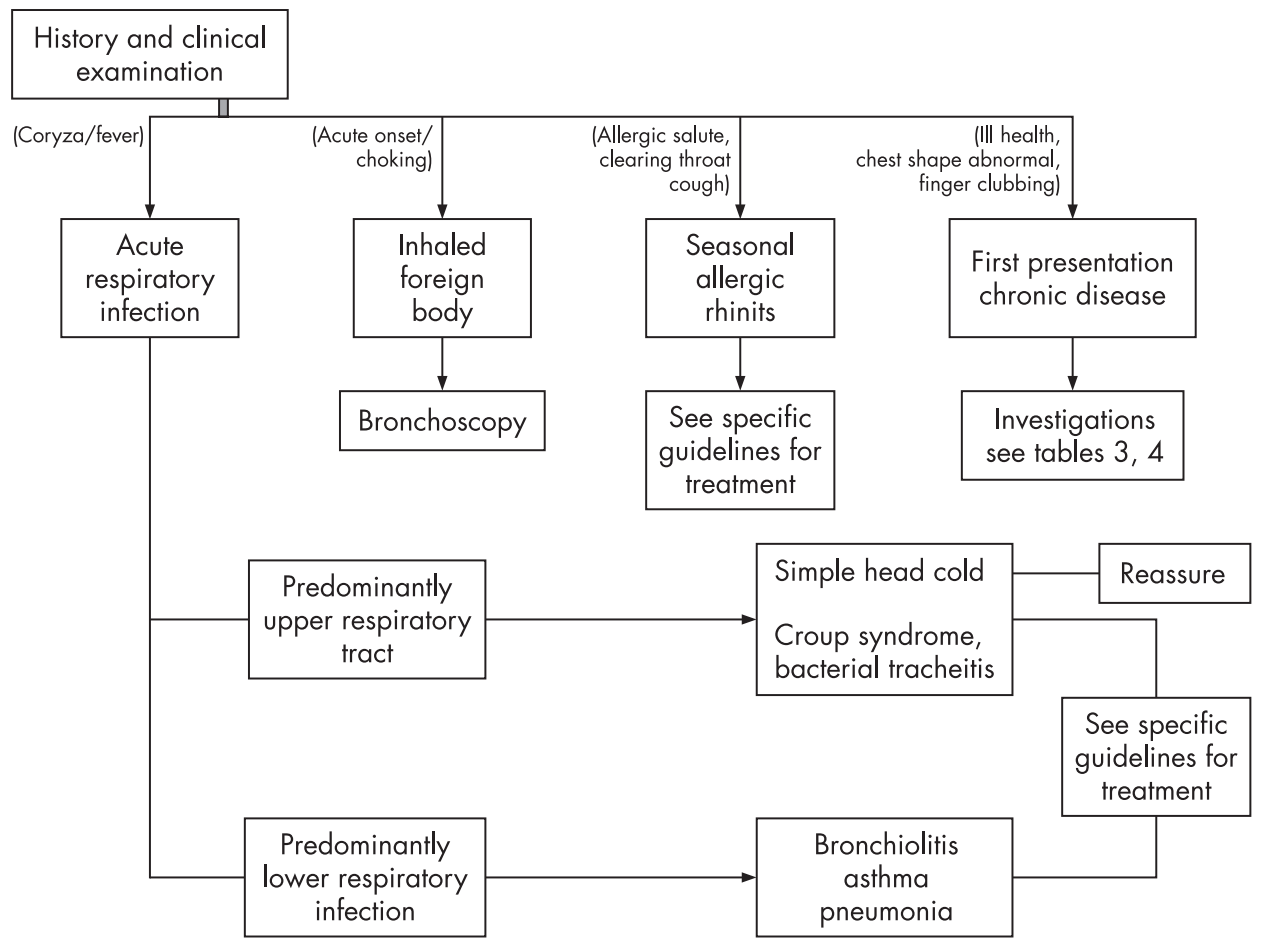

Education

- There may be benefits from educating the community and medical profession about the natural history of cough with head cold. For the majority of children the cough will have resolved by 14 days; however, for an important minority the cough will take 3-4 weeks to resolve. Giving this information to parents may reduce the need for subsequent doctor consultations, providing the cough is subsiding and provided that warnings are given about when to reconsult (eg, ongoing fever, tachypnoea).

\section{Prolonged acute cough (fig 3)}

There is a "grey" area between acute and chronic cough (cough lasting >8 weeks), sometimes called "subacute cough". Much coughing in children lasting $>3$ weeks is related to transient viral or pertussis-like infections. A period of observation (3-8 weeks) may therefore be needed to determine if further investigations will be required. If the cough is abating and the child is otherwise well, no further tests may be required; however, it will be important to follow-up the child in 6-8 weeks' time to ensure that the cough has resolved. If the cough is progressive or if a retained inhaled foreign body is likely, earlier investigations are required. Most acute coughs associated with upper respiratory infections should be abating in the second week, whereas a relentlessly progressive cough becomes increasingly severe (frequency and severity) beyond 2-3 weeks. In this situation, diagnoses that should be considered include pertussis, retained inhaled foreign body, expanding mediastinal neoplasm, lobar collapse secondary to mucus plug and tuberculosis (often with accompanying weight loss). A chest radiograph will usually be needed.
Figure 3 A simplified overview of the assessment and management of prolonged acute cough (3-8 weeks). A normal chest radiograph does not exclude an inhaled foreign body. FB, foreign body; TB, tuberculosis.

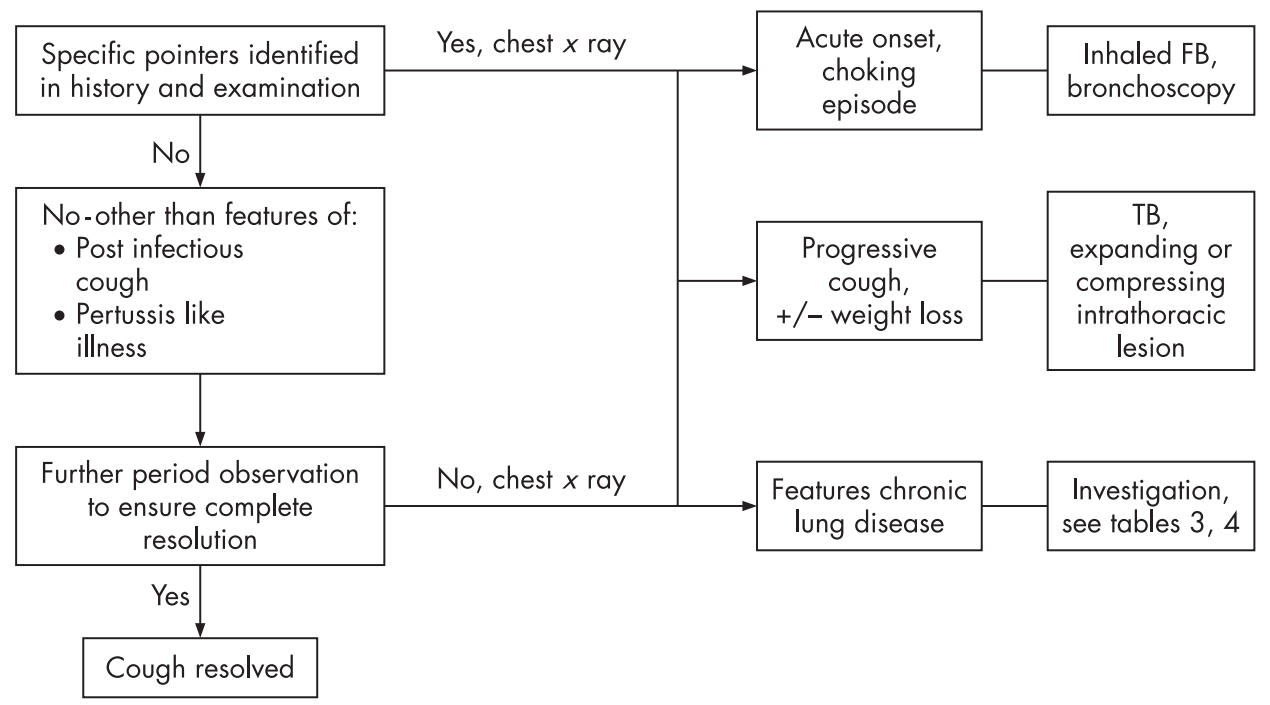


Figure 4 A simplified overview of the assessment and management of the common causes of chronic cough (>8 weeks). Boxes on the right hand side suggest diagnoses that are likely or at least need to be excluded. CF, cystic fibrosis; PCD, primary ciliary dyskinesia; PBB, protracted bacterial bronchitis; ID, immune deficiency; TB, tuberculosis: $\mathrm{BDR}$, bronchodilator responsiveness: PEFR, peak expiratory flow rate.

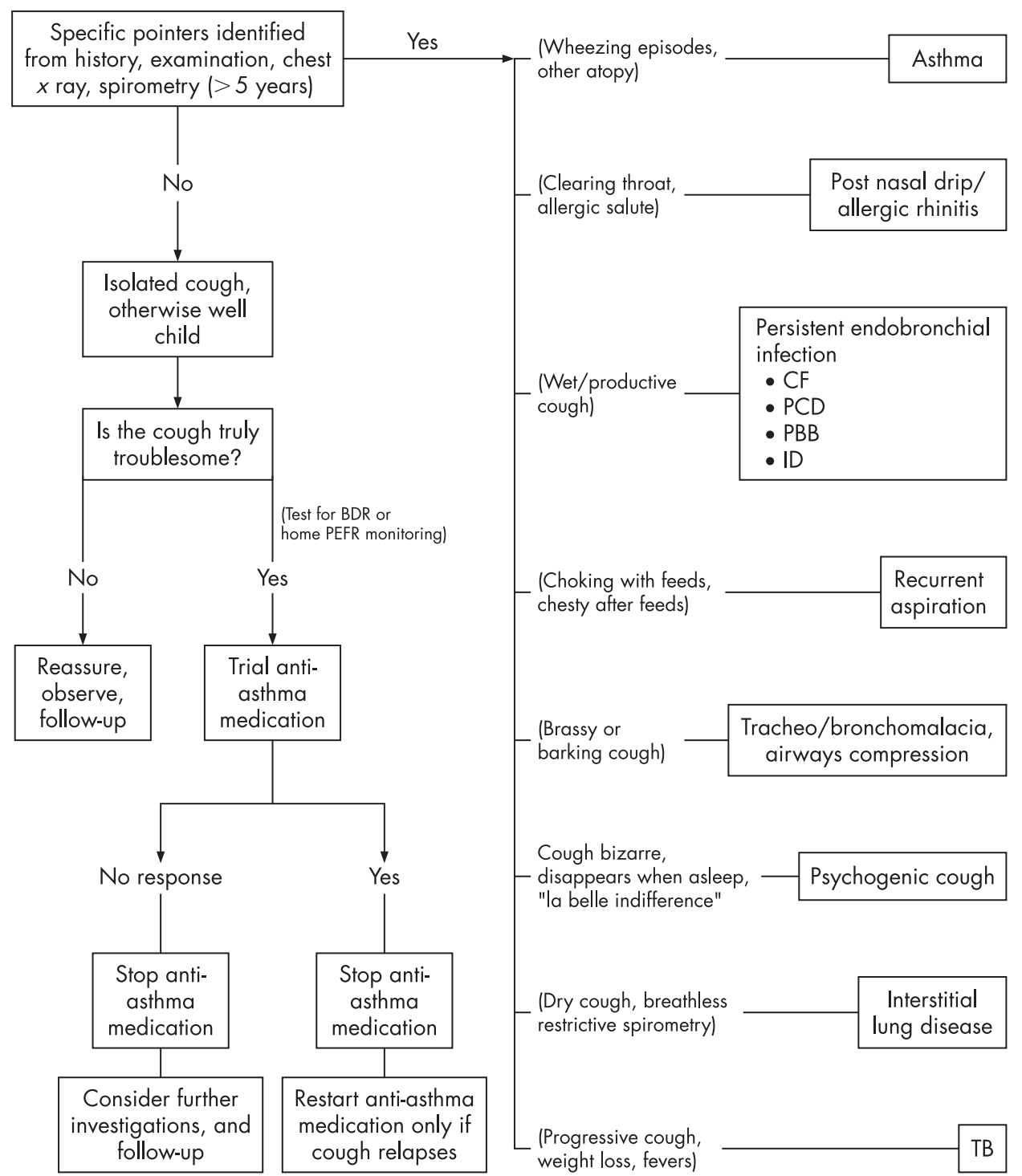

\section{Recurrent cough}

A recurrent cough without a cold is taken as repeated ( $\geqslant 2 /$ year) cough episodes - apart from those associated with head coldsthat each last more than 7-14 days. If the periods of resolution are short, frequently recurrent cough will be difficult to distinguish from persistent chronic cough.

\section{Chronic cough (fig 4)}

- The management of chronic coughing relates to first making an accurate underlying diagnosis and then applying specific treatment for that condition (see tables 4 and 5).

- Most chronic coughs in childhood are not due to the same conditions as occur in adults. The use of adult-based cough algorithms is unsuitable for application in children.

- The initial assessment should be used to identify pointers suggestive of specific disorders (see tables 3-5).

- A detailed history should be taken and all children with cough should have a full clinical examination.

- A chest radiograph is indicated for most children.

- Spirometry with or without tests of bronchodilator responsiveness (BDR) or bronchial hyperreactivity (BHR) should be attempted in children old enough to perform the manoeuvres.

- An attempt should be made to observe the cough and to obtain a sample of sputum.

- A "wet" moist productive cough is an alert that there is chronic overproduction of mucus and great care should be taken before such children are labelled as "asthmatic". Protracted bacterial bronchitis or a more serious condition such as cystic fibrosis should be considered.

- Allergy testing (skin prick or RAST specific testing) may be helpful in determining if a child is atopic and, in the correct background, that would make problem coughing more likely to be due to asthma.

- In otherwise well children with non-specific isolated dry coughing with no specific disease pointers, empirical trials of anti-asthma, anti-allergic rhinitis or anti-gastro-oesophageal reflux therapy are unlikely to be beneficial and are generally not recommended.

- However, as it can be difficult to rule out asthma as a cause of coughing in young children, a trial of anti-asthma therapy (typically inhaled corticosteroids) may be used. In such a trial the treatment should be effectively delivered in adequate doses with clearcut outcomes recorded. 
- A definite period of time should be set (eg, 8-12 weeks), after which the trial of anti-asthma medication should be stopped. If the child has responded to anti-asthma therapy and the treatment has subsequently been stopped, cough variant asthma is suggested by an early relapse that again responds to treatment. If there is no response, the treatment should be stopped as asthma is unlikely and the cough is unresponsive to asthma medication. This is important so that children with simple recurrent viral bronchitis or postviral cough do not end up on long-term high doses of inhaled corticosteroid.

- Psychotherapy regimes may be helpful in treating psychogenic coughing.

- An attempt should be made to remove children with chronic cough from exposure to aeroirritants such as environmental tobacco smoke.

- Non-specific isolated dry coughing in an otherwise well child should be differentiated from those with more serious conditions. "Red flag" alert symptoms/signs include:

- neonatal onset

- cough with feeding

- sudden onset cough

- chronic moist cough with phlegm production

- associated night sweats/weight loss

- continuous unremitting or worsening cough

- signs of chronic lung disease.

\section{ACUTE COUGH IN CHILDREN}

\section{Introduction}

Recommendation 1.1

- The majority of children with acute cough have a respiratory tract infection and an attempt should be made to arrive at a specific clinical diagnosis (table 1). ${ }^{22}$

Acute cough is usually caused by viral upper respiratory tract infection, probably with associated bronchitis in children but may arise from lower respiratory tract infections, hay fever, an inhaled foreign body or be the first presentation of a chronic disorder. Symptomatic upper respiratory tract infection with cough in school children typically occurs 7-10 times per year. $^{23} 24$

Prospective studies of acute cough in young children in general practice have suggested that about $50 \%$ recover by 10 days and $90 \%$ by 25 days, so $10 \%$ still have problems in the third to fourth weeks. This was supported by a recent systematic review of the natural history of acute cough in which it was estimated that about one-quarter will still be unwell with cough at 2 weeks. ${ }^{25} 26$

\section{Investigations}

\section{Recommendation 2.1}

- Most children with cough due to a simple upper respiratory tract infection will not need any investigations.

The absence of fever, tachypnoea and chest signs appear to be most useful for ruling out future complications in children with cough in primary care.

In a prospective cohort study of 222 children aged $0-4$ years in primary care with acute cough, the presence of fever, tachypnoea and chest signs were associated with an increased risk of subsequently developing a complication (any new symptom or sign suggestive of deterioration). Reconsultations occurred in $10 \%$ of cases which were mostly due to persisting symptoms; reported serious complications were rare with two hospital admissions for bronchiolitis and one for pneumonia. ${ }^{27} 28$

\section{Recommendation 2.2}

- Children in whom an inhaled foreign body is a likely cause of cough should have an urgent rigid bronchoscopy.

\section{Recommendation 2.3}

- A chest radiograph should be considered in the presence of lower respiratory tract signs, a cough that is relentlessly progressive beyond 2-3 weeks, haemoptysis or features of an undiagnosed chronic respiratory disorder (table 2).

While the cough associated with acute head cold may take 24 weeks to fully resolve, the cough severity and frequency is usually abating after the second week. Occasionally a child is seen with an acute onset cough which is relentlessly progressing in frequency and severity beyond 2-3 weeks. In this situation, diagnoses that should be considered include retained inhaled foreign body, expanding mediastinal neoplasm, lobar collapse secondary to mucus plug and tuberculosis (often with accompanying weight loss). Table 2 summarises some of the indications for performing a chest radiograph in a child with acute cough.

\section{Treatments: cough with simple head colds}

While parents report benefit from various over-the-counter preparations for treating children's cough, there is little evidence of a specific pharmacological effect.

\section{Recommendation 3.1}

- Over-the-counter medications are as effective as placebo for acute cough with head colds in children.

A systematic review of six RCTs and a further recent RCT found that over-the-counter antitussives, antihistamines and antihistamine-decongestant combinations were as effective as placebo with the potential for causing side effects. ${ }^{29}{ }^{30}$

\section{Recommendation 3.2}

- Bronchodilators are not effective for acute cough in non-asthmatic children.

RCTs of salbutamol versus placebo showed no beneficial effect for acute cough in non-asthmatic children. ${ }^{31}{ }^{32}$

\section{Recommendation 3.3}

- Antibiotics are generally not effective or recommended for treating acute coughs caused by simple "head colds".

While there is evidence that an early antibiotic prescription for children with coughing with "head colds" increases parental satisfaction, a systematic review of the evidence shows that antibiotics are not beneficial and may be associated with side effects. This included children with acute bronchitis and greencoloured sputum in the absence of signs of possible pneumonia. $^{33-35}$

\section{Recommendation 3.4}

- There may be benefits from educating the community and medical profession about the natural history of cough with head cold. 
Table 1 Questions to be addressed to arrive at a specific diagnosis for acute cough

\begin{tabular}{|c|c|c|}
\hline Question & Features & Likely common diagnoses \\
\hline $\begin{array}{l}\text { Is this an acute upper } \\
\text { respiratory infection? }\end{array}$ & Coryzal symptoms & $\begin{array}{l}\text { Simple head cold with } \\
\text { cough suggesting presence } \\
\text { of some degree of tracheitis } \\
\text { and/or bronchitis }\end{array}$ \\
\hline $\begin{array}{l}\text { Is this a croup } \\
\text { syndrome? }\end{array}$ & $\begin{array}{l}\text { Stridor with an associated } \\
\text { "barking" or "croupy cough". In } \\
\text { milder cases only the barking } \\
\text { cough may be present }\end{array}$ & $\begin{array}{l}\text { Viral croup } \\
\text { Recurrent spasmodic croup } \\
\text { Bacterial tracheitis } \dagger\end{array}$ \\
\hline $\begin{array}{l}\text { Are there any } \\
\text { features to suggest a } \\
\text { lower respiratory } \\
\text { tract illness? }\end{array}$ & $\begin{array}{l}\text { Tachypnoea*, respiratory } \\
\text { distress with increased work of } \\
\text { breathing, chest signs (crackles/ } \\
\text { wheeze) and fever }\end{array}$ & $\begin{array}{l}\text { Pneumoniał } \\
\text { Bronchiolitis§ } \\
\text { Asthma }\end{array}$ \\
\hline $\begin{array}{l}\text { Is there anything to } \\
\text { suggest an inhaled } \\
\text { foreign body? }\end{array}$ & $\begin{array}{l}\text { Very sudden onset or witnessed } \\
\text { choking episode }\end{array}$ & $\begin{array}{l}\text { Inhaled foreign body. } \\
\text { Bronchoscopy is indicated } \\
\text { on history alone to } \\
\text { diagnose and remove it. }\end{array}$ \\
\hline Is there anything to & Cough with other features of & Allergic rhinitis cough \\
\hline $\begin{array}{l}\text { suggest acute } \\
\text { pollinosis (hay fever)? }\end{array}$ & $\begin{array}{l}\text { "hay fever" in pollen season. } \\
\text { This cough is often described as } \\
\text { a "clearing the throat" cough }\end{array}$ & $\begin{array}{l}\text { True coughing may suggest } \\
\text { allergic tracheobronchial } \\
\text { inflammation }\end{array}$ \\
\hline $\begin{array}{l}\text { Is there anything to } \\
\text { suggest that this is a } \\
\text { presentation of a } \\
\text { chronic respiratory } \\
\text { disorder? }\end{array}$ & $\begin{array}{l}\text { Failure to thrive, finger clubbing, } \\
\text { over inflated chest, chest } \\
\text { deformity, features of atopy }\end{array}$ & See chronic cough section \\
\hline
\end{tabular}

*The respiratory rate varies with age and tachypnoea is defined as a respiratory rate of $>60 /$ min for children aged $<2$ months, $>50 /$ min for those aged 2-12 months and $>40 /$ min for children aged $>1$ year.

†Bacterial tracheitis is an uncommon but life-threatening condition in which children have a high temperature and progressive upper airways obstruction. The croupy cough helps to distinguish it from epiglottitis. These children usually need their airway secured and intravenous antibiotics to cover Staphylococcus aureus, Haemophilus influenzae B and streptococcal infections.

$\$$ Pneumonia is suggested if there is cough, fever and signs of respiratory distress in the absence of stridor or wheeze.

$\S$ Bronchiolitis is suggested in an infant with cough associated with crepitations, with or without audible wheeze during the winter respiratory syncytial virus season.

-Asthma is suggested if cough is associated with wheezing.

For the majority of children the cough will have resolved by 14 days but, for an important minority, the cough will take 34 weeks to resolve. Giving this information to parents may reduce the need for subsequent doctor consultations providing the cough is subsiding 2728 and provided that warnings are given about when to reconsult (eg, ongoing fever, tachypnoea).

\section{Recommendation 3.5}

- Parents should be warned that information obtained from the internet on cough may be unreliable.

According to one study of the 19 website pages identified in the year 2000, 10 contained more incorrect than correct information and only 1 appeared to be mostly correct. ${ }^{37}$

\section{Treatments: cough with specific diagnosis Recommendation 4.1}

- Evidence-based guidelines exist for treatment of the following common specific causes of acute cough and should be referred to: community-acquired pneumonia, ${ }^{38-40}$ croup, ${ }^{41}$ bronchiolitis, ${ }^{42-44}$ asthma. ${ }^{45}$

\section{Recommendation 4.2}

\section{- Macrolide antibiotics should be given early to children with pertussis.}

If pertussis has been diagnosed, macrolide antibiotics-if given very early (in the first 1-2 weeks) in the course of the diseasecan slightly alter the clinical course but their main role is to
Table 2 Suggested indications for performing a chest radiograph in a child with acute cough

\begin{tabular}{|c|c|c|}
\hline Indication & Features & Likely common diagnoses \\
\hline \multirow{5}{*}{$\begin{array}{l}\text { Uncertainty about the } \\
\text { diagnosis of pneumonia }\end{array}$} & Fever and rapid breathing in & \multirow{5}{*}{$\begin{array}{l}\text { Pneumonia } \\
\text { N.B. Chest radiograph is not } \\
\text { always indicated: use to } \\
\text { resolve uncertainty or in } \\
\text { more severe cases } \dagger\end{array}$} \\
\hline & $\begin{array}{l}\text { the absence of wheeze/ } \\
\text { stridor }\end{array}$ & \\
\hline & Localising signs in chest* & \\
\hline & $\begin{array}{l}\text { Persisting high fever or } \\
\text { unusual course in } \\
\text { bronchiolitis }\end{array}$ & \\
\hline & $\begin{array}{l}\text { Cough and fever persisting } \\
\text { beyond } 4-5 \text { days }\end{array}$ & \\
\hline
\end{tabular}

Possibility of an Choking episode may not inhaled foreign body have been witnessed but cough of sudden onset or presence of asymmetrical

Inhaled foreign body Expiratory film may help in acute bronchial obstruction, but normal chest radiograph does not exclude foreign body.

Bronchoscopy is the most important investigation.

Pointers suggesting

Failure to thrive

that this is a

Finger clubbing

See section on chronic presentation of a

chronic respiratory

Overinflated chest

disorder

Chest deformity

Unusual clinical

course

Cough is relentlessly
progressive beyond $2-$
3 weeks
Recurrent fever after initial
resolution

Pneumonia

Enlarging intrathoracic lesion Tuberculosis

Inhaled foreign body Lobar collapse

Is there true

haemoptysis?:

Acute pneumonia

Chronic lung disorder (eg, cystic fibrosis) Inhaled foreign body

Tuberculosis

Pulmonary haemosiderosis Tumour

Arteriovenous malformation

\footnotetext{
*Dull percussion, reduced air entry, crackles or bronchial breathing.

†Community-acquired pneumonia guidelines. ${ }^{38-40}$

\#True haemoptysis needs to be differentiated from spitting out blood secondary to nose bleeds, cheek biting, pharyngeal and oesophageal or gastric bleeding.
}

reduce the period of infectivity. ${ }^{46}$ However, the early stages of pertussis can be difficult to distinguish from a simple head cold, making this recommendation hard to carry out in practice other than in the situation when coughing starts after a known exposure. Azithromycin and clarithromycin are equally effective but have fewer side effects than erythromycin. ${ }^{47-49}$

Anecdotal evidence suggests that using salbutamol or steroids might reduce severity of the cough spasm in pertussis, but this has not been confirmed in RCTs. ${ }^{50}{ }^{51}$ A recent Cochrane review concluded that there was insufficient evidence (poor study quality) to draw conclusions about the efficacy of steroids, salbutamol or antihistamines in the symptomatic relief of coughing in pertussis. There were no statistically significant differences in coughs per $24 \mathrm{~h}$ or duration of hospitalisation between these interventions and placebo. ${ }^{52}$

\section{Recommendation 4.3}

- Antihistamines and intranasal steroids are beneficial for children with an allergic cough in the pollen season.

An RCT has shown that antihistamines are beneficial for reducing cough frequency and intensity during the pollen 
Table 3 Patterns, causes and potential investigations of chronic or frequently recurrent cough in otherwise healthy children

\begin{tabular}{|c|c|c|c|}
\hline & Pattern & Cause & Potential investigations \\
\hline \multirow{3}{*}{$\begin{array}{l}\text { Frequently recurring } \\
\text { viral bronchitis }\end{array}$} & \multirow{3}{*}{$\begin{array}{l}\text { Episodic, frequent in winter, associated with } \\
\text { "head colds", may occur "back-to-back" }\end{array}$} & Viral infections & None \\
\hline & & \multirow{2}{*}{$\begin{array}{l}\text { Crowded living conditions, ETS and attendance in } \\
\text { child care nursery }\end{array}$} & Chest radiography \\
\hline & & & $\begin{array}{l}\text { Examine during a period when symptom- } \\
\text { free }\end{array}$ \\
\hline \multirow[t]{2}{*}{ Postviral cough } & \multirow{2}{*}{$\begin{array}{l}\text { Troublesome cough (day and night) following a } \\
\text { respiratory infection and slowly resolving over } \\
\text { next } 2-3 \text { months }\end{array}$} & \multirow{2}{*}{$\begin{array}{l}\text { Viral respiratory infections, Chlamydia and } \\
\text { Mycoplasma infections }\end{array}$} & None, chest radiography, serology \\
\hline & & & $\begin{array}{l}\text { Consider trial of asthma therapy (some } \\
\text { mild asthmatics have prolonged recovery } \\
\text { from each viral infection) }\end{array}$ \\
\hline \multirow{2}{*}{$\begin{array}{l}\text { Pertussis and } \\
\text { pertussis-like illness }\end{array}$} & \multirow{2}{*}{$\begin{array}{l}\text { Troublesome spasmodic cough after initial } \\
\text { respiratory infection which slowly resolves over } \\
3-6 \text { months. Vomiting clear tenacious mucus. } \\
\text { Older child may complain of difficulty catching } \\
\text { breath }\end{array}$} & \multirow{2}{*}{$\begin{array}{l}\text { Bordetella pertussis, parapertussis, adenovirus, } \\
\text { influenza, parainfluenza }\end{array}$} & Nil \\
\hline & & & $\begin{array}{l}\text { Chest radiograph, positive serology or } \\
\text { culture may be helpful in reducing } \\
\text { requirements for further investigation }\end{array}$ \\
\hline \multirow[t]{3}{*}{ Cough variant asthma } & \multirow{3}{*}{$\begin{array}{l}\text { Isolated cough (no wheezing) due to asthma. } \\
\text { Confidence in diagnosis increased when strong } \\
\text { atopic background present and cough responds } \\
\text { rapidly to anti-asthma medication but relapses } \\
\text { when stopped }\end{array}$} & \multirow[t]{3}{*}{ Asthma } & $\begin{array}{l}\text { None, chest radiograph. Is airways } \\
\text { obstruction present and reversible? }\end{array}$ \\
\hline & & & BHR or BDR tests, \\
\hline & & & $\begin{array}{l}\text { Is there eosinophillic inflammation? Induced } \\
\text { sputum, allergy tests, FeNO, response to } \\
\text { asthma medication }\end{array}$ \\
\hline \multirow{4}{*}{$\begin{array}{l}\text { Allergic rhinitis, } \\
\text { postnasal drip and } \\
\text { sinusitis - cough } \\
\text { likely due to } \\
\text { concomitant } \\
\text { tracheobronchial } \\
\text { inflammation }\end{array}$} & \multirow{4}{*}{$\begin{array}{l}\text { Not fully accepted as a cause of cough. Cough } \\
\text { when "head hits the pillow" or constant throat } \\
\text { clearing by day. May have transverse nasal crease } \\
\text { of "allergic salute" }\end{array}$} & \multirow[t]{4}{*}{ Causes of allergic rhinitis } & $\begin{array}{l}\text { ENT examination, often no investigations } \\
\text { needed }\end{array}$ \\
\hline & & & Chest radiography, allergy tests \\
\hline & & & $\begin{array}{l}\text { Response to antirhinitis treatment within } \\
2 \text { weeks }\end{array}$ \\
\hline & & & CT scan of sinuses \\
\hline \multirow[t]{3}{*}{ Psychogenic cough } & Usually an older child/adolescent & Underlying stress & \multirow{3}{*}{$\begin{array}{l}\text { It is important to do investigations to } \\
\text { assure the doctor and parent that no major } \\
\text { disease is being missed. However, it is } \\
\text { important not to keep performing futile } \\
\text { investigations that may reinforce the } \\
\text { underlying problem }\end{array}$} \\
\hline & $\begin{array}{l}\text { (1) Tic-like "habit cough" persisting after head cold } \\
\text { or during times of stress }\end{array}$ & \multirow[t]{2}{*}{$\begin{array}{l}\text { Bizarre honking cough usually serving a purpose } \\
\text { with some secondary gain }\end{array}$} & \\
\hline & $\begin{array}{l}\text { (2) Bizarre disruptive honking cough with child } \\
\text { exhibiting "la belle indifference". Cough goes } \\
\text { away with concentration or sleep }\end{array}$ & & \\
\hline
\end{tabular}

ETS, exposure to environmental tobacco smoke; FeNO, fractional exhaled nitric oxide concentration; BDR, bronchodilator responsiveness; BHR, bronchial hyperreactivity.

season. ${ }^{53}$ Intranasal steroids may have an efficacy advantage over antihistamines. ${ }^{54}$

\section{CHRONIC COUGH IN CHILDREN}

\section{Introduction}

Most coughing in children is related to transient infections. A period of observation (3-8 weeks) may therefore be needed to determine if further investigations will be required. Indeed, in one study about $50 \%$ of children with apparent persistent nocturnal cough improved in the 2 weeks after presentation, irrespective of how long the cough had been going on before the time of assessment. ${ }^{55}$ If the cough is abating no further tests may be required, whereas if the cough is progressive or if a retained inhaled foreign body is likely, earlier investigations are required.

A recurrent cough without a cold is taken as repeated ( $\geqslant 2$ / year) cough episodes apart from those associated with head colds that each last more than 7-14 days. If the periods of resolution are short, recurrent cough will be difficult to distinguish from persistent chronic cough. In addition, many children with asthma syndromes or more serious underlying illnesses such as cystic fibrosis have recurrent cough with flareups during disease exacerbations. Therefore, in these guidelines, children with prolonged acute cough, chronic cough and recurrent cough are not specifically separated. Clinical experience suggests that most children with chronic cough have recurrent viral bronchitis (recurrent cough) or postviral syndromes (subacute cough) and are otherwise healthy. In a 2-year prospective cohort study, rhinovirus (32\%), pertussis (17\%) and respiratory syncytial virus $(11 \%)$ were the most frequent respiratory pathogens detected from children with prolonged coughing episodes, but other infections have been associated with prolonged cough including Mycoplasma, Chlamydia and adenovirus. ${ }^{56} 57$

\section{Classifications}

Generally, cough in children can be placed in one of three overlapping categories ${ }^{58}$ by a good history and thorough physical examination.

These three categories are:

\section{Normal child}

Recent objective audio recording studies suggest that normal children (currently free from upper respiratory tract infections) have, on average, 11 coughs each day with some experiencing more than 30 episodes per day. ${ }^{59}$ Cough frequency and severity increase during upper respiratory tract infections and some children experience recurrent upper respiratory tract infections (eg, 8-10 episodes, predominantly in the winter) with each new infection being associated with coughing that may last more than 7 days (eg, recurrent viral bronchitis). It is therefore difficult and requires experience to be sure when a child is normal. ${ }^{6162}$

\section{Specific cough}

After a detailed clinical assessment, pointers often suggest a specific diagnosis and requirement from additional investigations (tables 3 and 4).

\section{Non-specific isolated cough}

Clinical experience and epidemiological studies indicate that a significant number of children are otherwise well with no 
underlying serious illness and appear to have a "non-specific isolated persistent cough". This term has been used when an isolated dry cough persists with no other chest signs or symptoms in an otherwise completely well child in whom appropriate investigation has revealed no abnormality. ${ }^{58} 63$ "Non-specific isolated persistent cough" should not be thought of as a diagnosis in itself, but rather as a label. As these children truly have increased cough frequency and severity, ${ }^{64}$ there is probably a specific but as yet unidentified cause. Although the precise diagnosis is not available, it is possible that they have mild forms of the specific diagnoses listed in table 3 or very occasionally a more serious underlying condition (table 4).

Recent evidence suggests that only a small proportion of children with non-specific isolated persistent cough have asthma. They have different risk factors from classical asthma and only a small number subsequently develop asthma with wheezing. Bronchial hyperreactivity (BHR) is associated with the symptom of wheeze but not isolated dry or nocturnal cough, and is not predictive of the response to asthma treatment or the subsequent development of asthma. ${ }^{65-68}$ In addition, studies of airway inflammation that include induced sputum and bronchoalveolar lavage fluid suggest that only a small number of children with unexplained isolated cough have evidence of eosinophilic airways inflammation. ${ }^{69-71}$ Some of these children have heightened cough receptor sensitivity. ${ }^{72}$ The role of gastro-oesophageal reflux as a cause of isolated cough in otherwise well children is unclear. Gastro-oesophageal reflux is a frequent finding in infancy, with or without vomiting, and is only sometimes associated with cough symptoms.

\section{Evaluation}

When evaluating a child with a chronic cough, the key aims are to decide if:

- a diagnosis can easily be made clinically or whether it is necessary to perform further investigations to make a diagnosis or rule out certain more serious conditions;

- there are any effective treatments available or whether reassurance and support are all that is needed.

\section{Pointers in the history}

There is limited published evidence but much experience on which to make statements on how the characteristics of a cough relate to the underlying cause (table 5).

Traditionally, cough is characterised by its time of onset (neonatal, infancy and childhood), nature (dry or productive), its quality (brassy, croupy, honking, paroxysmal or staccato), the timing (persistent, intermittent, nocturnal and on awaking), triggering factors (cold air, exercise, feeding, seasonal, starts with a head cold), alleviating factors (bronchodilators, antibiotics) and presence of associated symptoms (eg, wheezing, shortness of breath).

\section{Recommendation 2.1}

- A detailed history should be taken and should address the following questions:

- How and when did the cough start?

- What is the nature and quality of the cough?

- Is the cough an isolated symptom?

- What triggers the cough?

- Is there a family history of respiratory symptoms, disorders and atopy?
Table 4 Potentially serious lung disorders with chronic coughing

\begin{tabular}{ll}
\hline Condition & Investigations \\
\hline Cystic fibrosis & $\begin{array}{l}\text { Sweat test, nasal potential difference, assessment of } \\
\text { pancreatic function, genotyping }\end{array}$
\end{tabular}

Immune deficiencies

Differential white cell counts, immunoglobulin levels and subsets, functional antibody responses and lymphocyte subset analysis

Primary ciliary disorders

Screening FnNO, saccharine test, cilial ultrastructure and function, culture of ciliated epithelium

Protracted bacterial bronchitis Chest radiography, sputum for culture, exclusion of other causes in this table. Response to 4-6 weeks antibiotic and physiotherapy

HRCT scan

Recurrent pulmonary aspiration: Barium swallow, videofluoroscopy, $24 \mathrm{~h} \mathrm{pH}$ studies, Laryngeal cleft or ' $\mathrm{H}$ ' type tracheo-oesophageal fistula

Post-TOF repair with swallowing incoordination Neuromuscular or neurodevelopmental disorder

GOR, hiatal hernia

Retained inhaled foreign body

Chest radiography and HRCT scan may show focal lung disease

Rigid bronchoscopy is both diagnostic and therapeutic and is almost always indicated if the history is suggestive of inhaled retained foreign body

Tuberculosis

Chest radiography, Mantoux, early morning gastric aspirates and gamma interferon tests

Anatomical disorder (eg, bronchomalacia) or lung malformation (eg, cystic congenital thoracic malformation)

Interstitial lung disease

Spirometry (restrictive defect), chest radiography and HRCT scan, lung biopsy

FnNO, fractional nasal nitric oxide; HRCT, high-resolution CT; TOF, tracheooesophageal fistula; GOR, gastro-oesophageal reflux.

*Fat-laden macrophages in bronchoalveolar lavage fluid may not be a specific test for recurrent pulmonary aspiration.

Most should have a chest radiograph and an attempt to obtain sputum for microbiology. A high-resolution CT scan may be indicated to determine the extent of disease, eg focal versus generalised.

- What medications is the child on, what treatments has the child had for the cough and what effect have they had on the cough frequency and severity?

- Does the cough disappear when asleep (suggests psychogenic or habit cough)?

- Does the child smoke cigarettes or exposed to environmental smoke?

\section{Recommendation 2.2}

- Cough starting in the neonatal period requires further investigation. All neonates and infants with an unexplained persistent cough should be observed feeding by an experienced nurse.

Chronic cough starting in the neonatal period usually indicates significant disease, especially if it starts in the first few days or weeks of life. Possible diagnoses include: 
Table 5 Questions to address in cough evaluation

\begin{tabular}{|c|c|c|}
\hline Question & Examples & Diagnosis \\
\hline \multirow{2}{*}{$\begin{array}{l}\text { How did the cough } \\
\text { start? }\end{array}$} & Very acute onset & Retained inhaled foreign body \\
\hline & Head cold & Infective cause (eg, postviral) \\
\hline \multirow{5}{*}{$\begin{array}{l}\text { When did the cough } \\
\text { start? }\end{array}$} & \multirow{5}{*}{$\begin{array}{l}\text { Neonatal onset (especially if in first few } \\
\text { days of life) }\end{array}$} & Aspiration \\
\hline & & Congenital malformation \\
\hline & & Cystic fibrosis \\
\hline & & Primary cilial dyskinesia \\
\hline & & Lung infection in utero \\
\hline \multirow[t]{13}{*}{$\begin{array}{l}\text { What is the quality } \\
\text { of the cough? }\end{array}$} & Productive ("moist or wet") & $\begin{array}{l}\text { Chronic suppurative lung disease } \\
\text { (bronchiectasis) eg, cystic fibrosis }\end{array}$ \\
\hline & $\begin{array}{l}\text { Paroxysmal spasmodic cough with or without } \\
\text { an inspiratory "whoop" and vomit }\end{array}$ & Pertussis or pertussis-like illness \\
\hline & \multirow{7}{*}{ Haemoptysis } & Cystic fibrosis \\
\hline & & Other bronchiectasis \\
\hline & & Retained inhaled foreign body \\
\hline & & Tuberculosis \\
\hline & & Tumour \\
\hline & & Pulmonary haemosiderosis \\
\hline & & Pulmonary arteriovenous malformation \\
\hline & $\begin{array}{l}\text { "Bizarre honking cough" in a child exhibiting } \\
\text { "la belle indifference" to the cough and } \\
\text { which increases with attention }\end{array}$ & Psychogenic cough \\
\hline & Dry repetitive cough, disappears with sleep & Habit cough \\
\hline & Brassy, barking or "seal-like" & $\begin{array}{l}\text { Tracheal or glottic cause (eg, tracheomalacia } \\
\text { and/or bronchomalacia) }\end{array}$ \\
\hline & Cough producing casts of the airways & Plastic bronchitis \\
\hline \multirow{4}{*}{$\begin{array}{l}\text { Is the cough relentlessly } \\
\text { progressive? }\end{array}$} & & Inhaled foreign body \\
\hline & & Lobar collapse \\
\hline & & Tuberculosis \\
\hline & & Rapidly expanding intrathoracic lesion \\
\hline \multirow{18}{*}{$\begin{array}{l}\text { Is the cough an isolated } \\
\text { symptom? }\end{array}$} & \multirow[t]{3}{*}{ Isolated cough (otherwise well) } & Non-specific isolated cough \\
\hline & & Recurrent viral bronchitis \\
\hline & & Psychogenic cough \\
\hline & \multirow[t]{7}{*}{ Associated wheezing present } & Asthma \\
\hline & & Retained inhaled foreign body \\
\hline & & Recurrent pulmonary aspiration \\
\hline & & Airways compression or tracheobronchomalacia \\
\hline & & $\begin{array}{l}\text { Bronchiolitis obliterans or interstitial lung } \\
\text { disease }\end{array}$ \\
\hline & & Neonatal chronic lung disease and rarely \\
\hline & & $\begin{array}{l}\text { Cardiac disease with either congestive heart } \\
\text { failure or large left to right shunts }\end{array}$ \\
\hline & \multirow[t]{7}{*}{$\begin{array}{l}\text { Associated ill health, recurrent pneumonia or } \\
\text { pulmonary infiltrates }\end{array}$} & $\begin{array}{l}\text { Cystic fibrosis } \\
\text { Immune deficiencies }\end{array}$ \\
\hline & & Primary cilial disorders \\
\hline & & Recurrent pulmonary aspiration \\
\hline & & Retained inhaled foreign body \\
\hline & & Tuberculosis \\
\hline & & Persistent bacterial bronchitis \\
\hline & & Anatomical disorder \\
\hline & $\begin{array}{l}\text { Associated shortness of breath and restrictive } \\
\text { lung defect }\end{array}$ & Interstitial lung disease \\
\hline \multirow{3}{*}{$\begin{array}{l}\text { What triggers the } \\
\text { cough? }\end{array}$} & Exercise, cold air, early morning & Asthma \\
\hline & Lying down & $\begin{array}{l}\text { Postnasal drip, gastro-oesophageal reflux } \\
\text { disease }\end{array}$ \\
\hline & Feeding & Recurrent pulmonary aspiration \\
\hline
\end{tabular}

- Aspiration: tracheo-oesophageal fistula or laryngeal cleft. A moist cough following feeding, irritability and arching after feeds or choking on feeds require further investigations.

- Congenital malformation: compression of airway or tracheobronchomalacia.

- Cystic fibrosis.

- Primary cilial dyskinesia, especially if there is chronic persistent rhinitis from birth.
Lung infection in utero or in perinatal period (eg, cytomegalovirus, respiratory syncytial virus, Chlamydia).

\section{Recommendation 2.3}

- Determine if the cough is wet and productive or dry.

It is worth determining if the cough is productive (wet/moist with sputum production versus dry). Reporting of this feature 
compares well with the amount of phlegm seen at bronchoscopy. ${ }^{73}$ A cough that sounds wet or productive implies either an increase in airway secretions or abnormalities in its clearance mechanisms. It may be difficult to be sure if a young child has a productive cough as most young children-and especially those $<5$ years of age-do not expectorate sputum but tend to swallow it. They often vomit and the sputum colour can be seen in the vomitus.

Dry non-productive cough may be suggestive of allergens in an allergic child, viral infections, tuberculosis or inhaled irritants.

- Children with isolated dry cough who appear otherwise healthy and have a normal chest radiograph could have one of the conditions listed in table 3. Children with stable asthma cough more frequently than controls and an increase in coughing heralds the onset of an exacerbation in children with asthma whose parents report cough to be a significant feature in their exacerbations. ${ }^{74}$ Many of the conditions listed in table 4 can be difficult to distinguish from asthma.

- Children with persistent productive (moist or wet) cough which may or may not be associated with ill health and recurrent pneumonia or pulmonary infiltrates on the chest radiograph should be investigated to determine if they have bronchiectasis or any of the specific suppurative lung conditions that eventually lead to bronchiectasis (table 4).

Cough productive of casts is unusual and suggests the rare plastic bronchitis. $^{75}$

\section{Recommendation 2.4}

- Determine whether the cough occurs in paroxysmal spasms and is associated with an inspiratory "whoop".

Paroxysmal spasmodic cough with or without an inspiratory "whoop" is the major feature of the pertussis syndromes with Bordetella pertussis being the most likely organism. ${ }^{56}{ }^{57} 76-78$ Posttussive vomiting often occurs.

Pertussis may be underdiagnosed in children and adolescents. In a community-based survey, parents reported cough lasting longer than 2 weeks in the past 12 months in $22 \%$ of children aged 5-14 years of age, 18\% of whom met the case definition for pertussis. ${ }^{77}$ In a second study, $37 \%$ of school-aged children with cough lasting $>2$ weeks had serological evidence of recent $B$ pertussis infection. Pertussis should be considered in any child coughing for $>2$ weeks (especially if associated with whooping or vomiting), even if the child has been previously immunised. ${ }^{78}$

A staccato-like cough in infancy has been described in Chlamydia infections. ${ }^{79}$

\section{Recommendation 2.5}

\section{- Determine if the cough is brassy, croupy or bizarre and honking.}

A brassy, barking or croupy cough is suggestive of tracheal or glottic irritation and children appeared distressed with the cough. ${ }^{80-86}$ A "seal-like" barking or brassy cough which is particularly severe with concomitant viral upper respiratory infection occurs in children with tracheal compressive lesions or in those with tracheomalacia, including the so-called "TOF cough" following repair of a tracheo-oesophageal fistula.

A disruptive bizarre honking cough in a child who exhibits "la belle indifference" suggests a psychogenic cough. ${ }^{87-92}$ Although the literature generally lumps together the bizarre honking psychogenic cough with habit coughs, clinical experience would suggest that habit coughs occur as a dry non-irritative repetitive coughing, often persisting long after a head cold has already resolved. Psychogenic and habit coughs generally increase when parents or teachers are present. Traditionally, these coughs are described as not being present at night. However, a recent case report using a cough monitor suggests that some do have increased cough at night. ${ }^{90}$

The condition of "psychogenic cough" is not well defined but the diagnosis implies that there is no underlying organic cause for the coughing. The underlying cause may relate to the secondary gain produced by the coughing (eg, absence from school). There is little information on how accurate clinical characteristics (table 5) are at identifying children with a nonorganic cause of coughing.

Suggestive features of non-organic coughing include:

- bizarre honking disruptive coughing;

- cough that obviously increases with attention and decreases with involvement and concentration in some activity or sleep;

- child exhibits "la belle indifference" to the disruptive coughing.

\section{Recommendation 2.6}

- Children with true haemoptysis require further investigation including a chest radiograph.

It is important to ensure that a child truly has haemoptysis. Apparent haemoptysis may be related to nose bleeds, cheek biting, haematemesis or factitious illness.

Causes of haemoptysis include:

- pneumonia/lung abscess

- chronic lung disease with bronchiectasis (eg, cystic fibrosis)

- retained inhaled foreign body

- tuberculosis

- pulmonary haemosiderosis

- tumour

- pulmonary arteriovenous malformation

- pulmonary hypertension

\section{Recommendation 2.7}

\section{- Determine if the cough is an isolated symptom.}

Children with coughing associated with wheezing or breathlessness should have the following conditions considered:

- asthma

- retained inhaled foreign body

- recurrent pulmonary aspiration

- airways compression or tracheobronchomalacia

- bronchiolitis obliterans or interstitial lung disease

- neonatal chronic lung disease

- cardiac disease with either congestive heart failure or large left-to-right shunts.

Other atopic disorders such as eczema or allergic rhinitis make a diagnosis of asthma more likely.

It is important to remember that parents may report associated shortness of breath with the bout of coughing and that this is different from true breathlessness when a child is not actually coughing.

\section{Recommendation 2.8}

\section{- Determine what triggers the cough.}

Children with asthma may cough with exercise (especially in cold air), excitement and at night. Children with psychogenic cough typically have increased cough when given attention by 
others and the cough disappears when the child is asleep. Swallowing or postprandial cough suggests the possibility of recurrent pulmonary aspiration.

\section{Recommendation 2.9}

- Determine if there is a family history of respiratory disorders.

A strong family history of asthma and other atopic disorders puts a child into the background that makes an asthma diagnosis more likely.

A history of tuberculosis or an elderly relative with a cough is important for the diagnosis of tuberculosis.

\section{Recommendation 2.10}

- Determine what medication the child is on.

Children treated with angiotensin-converting enzyme inhibitors may develop persistent cough. ${ }^{93} 94$ It is important to record what treatments have been used for the cough and what effect these have had.

\section{Pointers in the clinical examination}

Recommendation 3.1

- All children with cough should have a full clinical systematic examination including an assessment of the child's general health, height and weight centile, nutritional status and ENT examination.

Digital clubbing will be missed unless specifically sought, and asymmetric auscultatory signs also point to the need for further investigation.

A normal clinical examination does not exclude significant pathology. It is worth asking the child to cough or "huff" as part of the examination as this may help identify children with a loose wet cough.

ENT examination should include the external auditory meatus, looking for wax or a foreign body which may cause chronic cough possibly through stimulation of the auricular branch of the vagal nerve. ${ }^{95}$

Rarely, mannerisms associated with unusual stereotypic coughs would suggest Tourette's syndrome. ${ }^{96}$ However, the diagnosis of Tourette's syndrome cannot be made on a single tic, including isolated cough.

Cough can be a manifestation of congestive heart failure with pulmonary oedema which will occur most commonly in infancy.

\section{Investigations}

\section{Recommendation 4.1}

- A chest radiograph is indicated for most children with chronic cough.

A chest radiograph will give a good overview of the state of the lungs and may give indications for further investigations. A chest radiograph may not be indicated if a mild specific disorder is definitively diagnosed (asthma/allergic rhinitis or if a pertussis-like illness is clearly resolving). However, a normal chest radiograph does not always exclude significant pathology such as bronchiectasis and further imaging may be needed.

\section{Recommendation 4.2}

- Spirometry with or without tests of bronchodilator responsiveness (BDR) or bronchial hyperreactivity
(BHR) should be attempted in children old enough to perform the manoeuvres.

Spirometry also gives a good overview of the state of lung volumes and airways calibre. Unfortunately the presence of BHR in children with isolated cough is not predictive of the response to asthma treatment or the subsequent development of asthma. ${ }^{68} 9798$

\section{Recommendation 4.3}

- An attempt should be made to observe the cough and to obtain a sample of sputum.

This will be difficult in young children and may require help of an experienced physiotherapist. The sample can be sent for microbiological assessment (culture and sensitivity, virology including using PCR) and for differential cytology.

\section{Recommendation 4.4}

- Allergy testing (skin prick or RAST specific testing) may be helpful in determining if a child is atopic and in the correct background that would make problem coughing more likely to be due to asthma.

The presence or absence of pointers suggesting specific and serious lung disease will determine the requirements for more detailed investigations (tables 3-5).

In an otherwise healthy child with chronic dry or recurrent cough, the investigations may be initially limited to those for conditions in table 3 but careful follow-up is required to ensure no signs of more serious disease develop. A child presenting with chronic productive cough and signs of chronic respiratory disease will require assessment for the conditions listed in table 4.

\section{Treatment of chronic cough}

Recommendation 5.1

- The use of adult-based cough algorithms are unsuitable for application in children.

Marchant et a ${ }^{99}$ found that asthma, gastro-oesophageal reflux or upper respiratory disorders were the cause of cough in fewer than $10 \%$ of patients at a tertiary referral unit. The "big three" causes of adult chronic cough (cough variant asthma, postnasal drip and gastro-oesophageal reflux) are not necessarily valid for children. ${ }^{13}$

\section{Recommendation 5.2}

- An attempt should be made to remove children with chronic cough from exposure to aeroirritants such as environmental tobacco smoke.

Children cough more if they are passive smokers and this is usually secondary to parental smoking. There is considerable evidence that exposure to environmental irritants such as cigarette smoke and home pollutants (such as nitrogen dioxide and $\mathrm{PM}_{10}$ particles) is associated with increased coughing.

Although there is little information to show that removal from these aeroirritants is helpful, it seems sensible to try and remove the child from such exposures. ${ }^{100-103}$ The adolescent who develops a recurrent or persistent cough should be suspected of cigarette smoking.

\section{Treatments: cough with a specific diagnosis Recommendation 6.1}

- The management of chronic coughing relates to first making an accurate underlying diagnosis and then applying specific treatment for that condition. 
Evidence-based guidelines and review articles exist for treatments of the following specific disorders associated with cough and should be referred to: asthma; cystic fibrosis; immune deficiencies; primary ciliary dyskinesia; tuberculosis.

\section{Recommendation 6.2}

- Children with protracted bacterial bronchitis should first have other underlying conditions excluded and sputum cultured before this diagnosis is made. A trial treatment of physiotherapy and a prolonged course (eg, 4-6 weeks) of appropriate antibiotics may be tried.

There have been considerable concerns about using the term "chronic bronchitis" in children with worries that asthma and more serious underlying conditions may be missed. Juvenile chronic bronchitis with persistent endobronchial infection (recently labelled persistent bacterial bronchitis) has been described for many decades. ${ }^{104-112}$ Children have chronic or recurrent cough with sputum production. This term should only be used after underlying causes have been excluded (table 4). Despite these concerns, there appears to be a group of children who have persistent productive cough in whom other underlying diagnoses have been excluded and for whom anti-asthma therapy has failed. For these children, a trial of intensive physiotherapy and a prolonged course of an appropriate antibiotic may be useful. A recent Cochrane review of antibiotics for prolonged moist cough in children found two suitable but not high quality studies that suggest beneficial effects from using antibiotics in this situation, but cautioned that antibiotics also have their own side effects. ${ }^{113-115}$ In a recent study using an adult-based algorithm approach to the child with chronic cough (majority with wet cough), the most common final diagnosis was "protracted bacterial bronchitis" and this condition may therefore be more common than previously thought..$^{9}$ Further research is needed to determine how frequent this condition is and whether it is a precursor to bronchiectasis or chronic obstructive pulmonary disease in adulthood.

\section{Treatments: non-specific isolated cough in an otherwise well child}

The evidence base for treating children with non-specific persistent isolated cough (which includes postviral cough and recurrent viral bronchitis) is sparse and no treatments seem particularly effective. Parental reassurance is required and usually the cough eventually subsides with the passage of time. If the impact of the cough is mild and there are no diagnostic pointers in an otherwise well child, a period of observation with no diagnostic tests or treatments should be considered.

\section{Recommendation 7.1}

-Whenever specific work-up is not pursued as part of the management plan, this should be time limited (eg, 6-8 weeks) and a comprehensive review performed to ensure that the cough is resolved and no specific pointers have developed.

\section{Recommendation 7.2}

- In otherwise well children with non-specific isolated coughing with no specific disease pointers, empirical trials of anti-asthma, anti-allergic rhinitis or antigastro-oesophageal reflux therapy are unlikely to be beneficial and are generally not recommended.

\section{Asthma therapy}

Anti-asthma therapy has not been shown to be effective for children with non-specific persistent isolated cough (either not effective or insufficient evidence).

- Two RCTs have compared inhaled corticosteroids (beclomethasone, fluticasone) with placebo for treating children with isolated non-specific cough. A small beneficial effect was observed only for the study using very high dose fluticasone but the author advises caution regarding the potential for side effects. ${ }^{55} 98$

- There is currently insufficient evidence (no RCTs) to support the use of inhaled anticholinergics ${ }^{14}$ in the treatment of persistent non-specific cough in children.

- There is currently insufficient evidence (no RCTs) to support the use of theophyllines in the treatment of persistent non-specific cough in children. ${ }^{15}$

- There is currently insufficient evidence (no RCTs) to support the use of inhaled cromones ${ }^{16}$ in the treatment of persistent non-specific cough in children.

- One RCT was unable to show a therapeutic advantage of ketotifen over placebo for treating infants and young children $<3$ years with chronic cough (or wheeze). ${ }^{116}$

- There is currently insufficient evidence (no RCTs) to support the use of leucotriene receptor antagonists in the treatment of persistent non-specific cough in children. ${ }^{117}$

It can be difficult to determine whether a child with nonspecific isolated coughing has underlying cough predominant asthma and therefore might respond well to anti-asthma treatment. Many practitioners therefore now recommend a "trial of anti-asthma therapy" for young children with isolated coughing (conditions listed in table 1) as a test for asthma. This practice is less than ideal but results from an imprecise definition of asthma and lack of suitable available tests to confirm a diagnosis of asthma in young children.

\section{Recommendation 7.3}

- If a trial of anti-asthma therapy is used to diagnose problem coughing as being caused by asthma, the treatment should be effectively delivered in adequate doses and clearcut outcomes recorded.

A definite period of time should be set (eg, 8-12 weeks) after which the trial of anti-asthma medication should be stopped.

Before embarking on a "therapeutic trial" of asthma medication, it is worth first attempting to document bronchial hyperresponsiveness (eg, peak flow variability during a period of home monitoring, forced expiratory volume in $1 \mathrm{~s}$ response to acute administration of bronchodilator, or an acute bronchoconstriction to a simple exercise test).

When using a "trial of medication" to make a diagnosis of cough variant asthma, it is important that the treatment is effectively delivered in adequate doses and that clear outcomes are recorded by parents. The response to short-acting bronchodilators should be recorded to determine if they provide shortterm relief of coughing. In order to clearly confirm or exclude a diagnosis of asthma, inhaled corticosteroids are likely to be required (eg, beclometasone dipropionate or budesonide $400 \mu \mathrm{g}$ per day for the defined period of 8-12 weeks). Alternatively, for those with chronic cough (regular daily or nocturnal), a therapeutic trial of oral steroid (eg, prednisolone $1-2 \mathrm{mg} / \mathrm{kg}$ for 3-5 days) is an effective tool to resolve symptoms quickly and point to a diagnosis of asthma. ${ }^{118}$

If a child has frequently recurrent cough lasting more than 2 weeks with "head colds" but completely recovering in 
between that might be due to asthma, a longer period of treatment (eg, 8-12 weeks) would be required to determine whether the cough frequency and severity of the episodes has been reduced.

If the child has responded to anti-asthma therapy and the treatment has subsequently been stopped, cough variant asthma is suggested by an early relapse that again responds to treatment. If there is no response the treatment should be stopped as asthma is unlikely and the cough is unresponsive to asthma medication. This is important so that children with simple recurrent viral bronchitis or postviral cough do not end up on long-term high doses of inhaled corticosteroid.

\section{Postnasal drip and rhinosinusitis therapy}

It has been suggested that allergic rhinitis and sinusitis are associated with cough that results from postnasal drip and irritation of the larynx, although the evidence behind this is lacking. ${ }^{119} 120$ The typical adult symptoms of sensation of secretions dripping down the posterior pharynx from the back of the nose and frequent "throat clearing" type of cough may be difficult to elucidate from a child. Children with chronic allergic rhinitis may have a transverse nasal crease due to the "allergic salute" from frequent nose rubbing. When a true harsh self-propagating cough is present, it is unlikely that treatment of nasal secretions will be beneficial as it is likely that the same pathological process occurs in both the nose and the laryngotracheobronchial tree. In adults a major diagnostic criterion is response to treatment. Sinusitis has been described in association with allergic rhinitis and asthma in children. ${ }^{121-123}$

\section{Recommendation 7.4}

- In children with a throat clearing type of cough and signs of allergic rhinitis, allergen avoidance and a trial of therapy is indicated.

Allergen avoidance, oral antihistamines and intranasal corticosteroids are the cornerstones of management. ${ }^{124}$

\section{Recommendation 7.5}

- Empirical gastro-oesophageal reflux therapy is not indicated for non-specific cough in children.

Although non-controlled studies have found improvement of cough with treatment for gastro-oesophageal reflux, a recent Cochrane review showed that there was a lack of data on which to base recommendations for the empirical treatment of gastrooesophageal reflux in children with cough. ${ }^{125-127}$

\section{Recommendation 7.6}

- In arriving at a diagnosis of psychogenic or habit cough, the physician should first be sure that organic causes are unlikely and that the suggestive features are present.

Suggestive features of non-organic coughing include:

- bizarre honking disruptive coughing;

- cough that obviously increases with attention and decreases with involvement and concentration in some activity or sleep;

- child exhibits "la belle indifference" to the disruptive coughing

Habit or "tic"-like coughs are generally less disruptive.

\section{Recommendation 7.7}

- Psychotherapy such as behaviour modification regimes may be helpful in treating psychogenic coughing. ${ }^{87-92}$

Acknowledgements: The following people read these guidelines during their formation and provided detailed feedback with helpful suggestions for improvements to make these guidelines more generalisable: Dr Vincent McGovern, Children's Respiratory Clinic, Royal Belfast Hospital for Sick Children, Belfast; Dr Robert Carroll, Grove Medical Practice, Skegoneill Health Centre, Belfast; Dr Naoimh White, Department of General Practice, Dunluce Health Centre, Belfast; Dr Neil Kennedy, Department of Child Health, Queen's University Belfast; Dr Dara O'Donoghue, Royal Belfast Hospital Sick Children, Belfast; Dr Jenny Hughes, Royal Belfast Hospital Sick Children, Belfast.

Competing interests: None.

\section{REFERENCES}

1. Hay AD, Heron J, Ness A. The prevalence of symptoms and consultations in preschool children in the Avon Longitudinal study of Parents and Children (ALSPAC): a prospective cohort study. Fam Pract 2005;22:367-74.

2. Clough JB, Williams JD, Holgate ST. Effect of atopy on the natural history of symptoms, peak expiratory flow, and bronchial responsiveness in 7- and 8-year old children with cough and wheeze. Am Rev Respir Dis 1991;43:755-60.

3. Ninan T, MacDonald L, Russel G. Persistent nocturnal cough in childhood: a population based study. Arch Dis Child 1995;73:403-7.

4. Burr ML, Anderson HR, Austin JB, et al. Respiratory symptoms and home environment in children: a national survey. Thorax 1999;54:27-32.

5. Thomson F, Masters IB, Chang AB. Persistent cough in children and the overuse of medications. J Paediatr Child Health 2002;38:578-81.

6. McKenzie S. Cough - but is it asthma? Arch Dis Child 1994;70:1-2.

7. Cornford CS, Morgan M, Ridsdale L. Why do mothers consult when their children cough? Fam Pract 1993;10:193-6.

8. Kai J. What worries parents when their preschool children are acutely ill, and why: a qualitative study. BMJ 1996;313:983-6.

9. Archer LNJ, Simpson H. Night cough counts and diary cough scores in asthma. Arch Dis Child 1985:60:473-4.

10. Chang AB, Newman RG, Carlin J, et al. Subjective scoring of cough in children: parental-completed vs child completed diary cards vs an objective method. Eur Respir J 1998:11:462-6.

11. Shann F. How often do children cough? Lancet 1996;348:699-700.

12. Falconer A, Oldman C, Helms P. Poor agreement between reported and recorded nocturnal cough in asthma. Pediatr Pulmonol 1993;15:209-11.

13. Chang AB. Cough: are children really different to adults? Cough 2005;1:7. http:/ www.coughjournal.com/content/1/1/7.

14. Chang $\mathbf{A B}, \mathbf{M c K e a n} \mathbf{M}$, Morris P. Inhaled anti-cholinergics for prolonged nonspecific cough in children. Cochrane Database Syst Rev 2004;(1):CD004358.

15. Chang AB, Halstead RA, Petsky HL. Methylxanthines for prolonged non-specific cough in children. Cochrane Database Syst Rev 2005;(3):CD005310.

16. Chang $\mathbf{A B}$, Marchant JM, Morris P. Cromones for prolonged non-specific cough in children. Cochrane Database Syst Rev 2004;(1).

17. Chang AB, Lasserson TJ, Gaffney J, et al. Gastro-oesophageal reflux treatment for prolonged non-specific cough in children and adults. Cochrane Database Syst Rev 2005;(2):CD004823.

18. Irwin RS, Madison JM. The diagnosis and treatment of cough. $N$ Eng/ J Med 2000;343:1715-21.

19. Sherrill DL, Guerra S, Minervini MC, et al. The relationship of rhinitis to recurrent cough and wheezing: a longitudinal study. Respir Med 2005;99:1377-85.

20. Chang AB, Phelan PD, Sawyer SM, et al. Airway hyperresponsiveness and cough receptor sensitivity in children with recurrent cough. Am J Respir Crit Care Med 1997; 155:1935-9.

21. Marais BJ, Gie RP, Obihara CC, et al. Well defined symptoms are of value in the diagnosis of childhood pulmonary tuberculosis. Arch Dis Child 2005;90:1162-5.

22. Hay AD, Schroeder K, Fahey T. Acute cough in children. 10-minute consultation. BMJ 2004;328:1062

23. Monto AS. Studies of the community and family: acute respiratory illness and infection. Epidemiol Rev 1994;16:351-73.

24. Leder K, Sinclair MI, Mitakakis TZ, et al. A community based study of respiratory episodes in Melbourne, Australia. Aust NZ J Public Health 2003;27:399-404.

25. Hay AD, Wilson A, Fahey $T$, et al. The duration of acute cough in pre-school children presenting to primary care: a prospective cohort study. Fam Pract 2003;20:696705.

26. Hay AD, Wilson AD. The natural history of acute cough in children aged 0-4 years in primary care: a systematic review. Br J Gen Pract 2005;52:401-9.

27. Butler CC, Hood K, Kinnersley P, et al. Predicting the clinical course of suspected acute viral upper respiratory tract infection in children. Fam Pract 2005;22:92-5.

28. Hay AD, Fahey T, Peters TJ, et al. Predicting complications from acute cough in preschool children in primary care: a prospective cohort study. Br J Gen Pract 2004:54:9-14. 
29. Schroeder K, Fahey T. Should we advise parents to administer over the counter cough medicines for acute cough? Systematic review of randomized controlled trials. Arch Dis Child 2002;86:170-5.

30. Paul I, Yoders KE, Crowell KR, et al. Effect of dextromethorphan, diphenylhydramine, and placebo on nocturnal cough and sleep quality for coughing children and their parents. Pediatrics 2004;114:e85-90.

31. Bernard DW, Goepp JG, Duggan AK, et al. Is oral albuterol effective for acute cough in non-asthmatic children. Acta Paediatr 1999;88:465-7.

32. Smucry JJ, Flynn CA, Becker LA, et al. Are $\beta 2$ agonists effective treatment for acute bronchitis or acute cough in patients without underlying pulmonary disease? A systematic review. J Fam Pract 2001;50(11).

33. Christakis DA, Wright JA, Taylor JA, et al. Association between parental satisfaction and antibiotic prescription for children with cough and cold symptoms. Pediatr Infect Dis J 2005:24:774-7.

34. Arroll B, Kenealy T. Antibiotics for the common cold and purulent rhinitis. Cochrane Database Syst Rev 2002;(3):CD000247.

35. Scott NCH. Management and outcome of winter upper respiratory tract infections in children aged 0-9 years. BMJ 1979;1:29-31.

36. Little $\mathbf{P}$, Rumsby K, Kelly J, et al. Information leaflet and antibiotic prescribing strategies for acute lower respiratory tract infection. A randomized controlled trial. JAMA 2005;293:3029-35.

37. Pandolfini C, Impicciatore $\mathrm{P}$, Bonati M. Parents on the web: risks for quality management of cough in children. Pediatrics 2000;105:e1.

38. World Health Organisation. The management of acute respiratory infections in children. In: Practical guidelines for outpatient care. Geneva: WHO, 1995.

39. British Thoracic Society. BTS guidelines for the management of community acquired pneumonia in childhood. Thorax 2002;57(Suppl 1):377-470.

40. Lakhanpaul M, Atkinson M, Stephenson T. Community acquired pneumonia in children: a clinical update. Arch Dis Child Educ Pract Ed 2004;89:ep29-34.

41. Anon. Croup. Clinical Evidence 2004;12:370-84.

42. Anon. Bronchiolitis. Clinical Evidence 2004;12:401-26.

43. Scottish Intercollegiate Guidelines Network (SIGN). Bronchiolitis in children SIGN Publication No 91, 2006. http://www.sign.ac.uk.

44. Perlstein PH, et al. Evaluation of an evidence-based guideline for bronchiolitis. Pediatrics 1999;104:1334-41.

45. British Thoracic Society (BTS)/Scottish Intercollegiate Guidelines Network (SIGN). British guideline on the management of asthma. Thorax 2003;58(Suppl 1):1-83.

46. Bergquist So, Bernander S, Dahnsjo $\mathrm{H}$, et al. Erythromycin in the treatment of pertussis: a study of bacteriological and clinical effects. Pediatr Infect Dis $J$ 1987;6:458-61

47. Tiwari T, Murphy TV, Moran J. Recommended antimicrobial agents for the treatment and postexposure prophylaxis of pertussis. 2005 CDC guidelines. Morbidity and Mortality Weekly Report Recommendations and Reports (MMWR) 2005:54(RR-14):1-13.

48. Pillay V, Swingler G. Symptomatic treatment of the cough in whooping cough (review). Cochrane Database Syst Rev 2003;(4):CD003257.

49. Crowcroft NS, Pebody RG. Recent developments in pertussis. Lancet 2006;367:1926-36.

50. Mertsola J, Viljanen M, Ruuskanen 0. Salbutamol in the treatment of whooping cough. Scand J Infect Dis 1986;18:593-4.

51. Torre D, Tambini R, Ferrario G, et al. Treatment with steroids in children with pertussis. Pediatr Infect Dis J 1993;12:419-20.

52. Pillay V, Swingler G. Symptomatic treatment of the cough in whooping cough. Cochrane Database Syst Rev 2003;(4):CD003257

53. Ciprandi G, Tosca M, Ricca V, et al. Cetirizine treatment of allergic cough in children with pollen allergy. Allergy 1997;52:752-4.

54. Rodrigo GJ. Intranasal corticosteroids versus topical H1 receptor antagonists for the treatment of allergic rhinitis: a systematic review with meta-analysis. Ann Allergy Asthma Immunol 2002;89:479-84.

55. Davies MJ, Fuller $\mathrm{P}$, Picciotto $\mathrm{A}$, et al. Persistent nocturnal cough: randomized controlled trial of high dose inhaled corticosteroids. Arch Dis Child 1999;81:38-44.

56. Versteegh FG, Weverling GJ, Peeters MF, et al. Community-acquired pathogens associated with prolonged cough in children: a prospective cohort study. Clin Microbiol Infect 2005;10:801-7.

57. Hallander HO, Gnarpe J, Gnarpe H, et al. Bordetella pertussis, Bordetella parapertussis, Mycoplasma pneumoniae and persistent cough in children. Scand J Infect Dis 1999;31:281-6.

58. Chang AB. Causes, assessment and measurement of cough in children. In: Chung KF, Widdicombe JG, eds. Cough: causes, mechanisms and therapy. Oxford: Blackwell Publishing, 2003:58-73.

59. Munyard P, Bush A. How much coughing is normal? Arch Dis Child 1996;74:5314.

60. Shann F. How often do children cough? Lancet 1996;348:699-700.

61. Bush A, Price JP. Childhood asthma syndromes. In: Gibson GJ, Geddes DM, Costabel U, et al, eds. Respiratory medicine. 3rd ed. Philadelphia: Saunders, 2003:1396-420.

62. Bush A. Pediatric problems of cough. Pulm Pharmacol Ther 2002;15:309-15.

63. Saglani S, McKenzie SA. The management of persistent isolated cough in childhood. Curr Paediatr 2002;12:1-6.

64. Chang $\mathbf{A B}$, Phelan PD, Robertson CF, et al. Frequency and perception of cough severity. J Paediatr Child Health 2001;37:142-5.
65. Chang AB. Cough, cough receptors, and asthma in children. Pediatr Pulmonol 1999;28:59-70.

66. Kelly YJ, Brabin BJ, Milligan, et al. Clinical significance of cough and wheeze in the diagnosis of asthma. Arch Dis Child 1996;75:489-93.

67. Wright AL, Holberg CJ, Morgan WJ, et al. Recurrent cough in childhood and its relation to asthma. Am J Respir Crit Care Med 1996;153:1259-65.

68. Brooke AM, Lambert PC, Burton PR, et al. Recurrent cough: natural history and significance in infancy and early childhood. Pediatr Pulmonol 1998;26:256-61.

69. Zimmerman B, Silverman FS, Tarlo SM, et al. Induced sputum: comparison of postinfectious cough with allergic asthma in children. J Allergy Clin Immunol 2000; 105:495-9

70. Gibson PG, Simpson JL, Chalmers AC, et al. Airways eosinophilia is associated with wheeze but is not common in children with persistent cough and frequent chest colds. Am J Respir Crit Care Med 2001;164:977-81.

71. Fitch PS, Brown V, Schock B, et al. Chronic cough in children: bronchoalveolar lavage findings. Eur Respir J 2000;16:1109-14.

72. Chang AB, Phelan PD, Sawyer SM, et al. Cough sensitivity in children with asthma, recurrent cough and cystic fibrosis. Arch Dis Child 1997;77:331-4.

73. Chang AB, Gaffney JT, Eastburn MM, et al. Cough quality in children: a comparison of subjective vs. bronchoscopic findings. BioMedCentral Respiratory Research. http://respiratory-research.com/content/6/1/3 (accessed 4 Feb 2008).

74. Li AM, Lex C, Zacharasiewicz A, et al. Cough frequency in children with stable asthma: correlation with lung function, exhaled nitric oxide, and sputum eosinophil count. Thorax 2003;58:974-8.

75. Kao NL, Richmond GW. Cough productive of casts. Ann Allergy Asthma Immunol 1996;76:231-3.

76. Cagney M, Maclntyre R, Maclntyre P, et al. Cough symptoms in children aged 5 15 years in Sydney, Australia: non-specific cough or unrecognized pertussis? Respirology 2005;10:359-64.

77. Jenkinson D. Natural course of 500 consecutive cases of whooping cough: a general practice population study. BMJ 1995;310:299-302.

78. Harnden A, Grant C, Harrison T, et al. Whooping cough in school age children with persistent cough: prospective cohort study in primary care. BMJ 2006;333:174-7.

79. Schaad UB, Rossi E. Infantile Chlamydia pneumonia: a review based on 115 cases. Eur J Pediatr 1982;138:105-9.

80. Chetcuti P, Phelan PD. Respiratory morbidity following repair of oesophagea atresia and tracheo-oesophageal fistula. Arch Dis Child 1993;68:167-70.

81. Wood RE. Localized tracheomalacia or bronchomalacia in children with intractable cough. J Pediatr 1997;116:404-6.

82. Finder JD. Primary bronchomalacia in infants and children. J Pediatr 1997;130:5966.

83. Masters IB, Chang AB, Patterson L, et al. Series of laryngomalacia, tracheomalacia and bronchomalacia disorders and their associations with other conditions in children. Pediatr Pulmonol 2002;34:189-95.

84. Wood RE. Localised tracheomalacia or bronchomalacia in children with intractable cough. J Pediatr 1997;116:404-6.

85. Gormley PK, Colreavy MP, Patil N, et al. Congenital vascular anomalies and persistent respiratory symptoms in children. Int J Pediatr Otorhinolaryngol 1999;51:23-31.

86. Cherry JD. The treatment of croup: continued controversy due to failure of recognition of historic, ecological, etiologic and clinical perspectives. J Pediatr 1979;94:352-4.

87. Gay M, Blager F, Bartsch K, et al. Psychogenic habit cough: review and case reports. J Clin Psychiatry 1987:48:483-6.

88. Lavigne JV, Davis T, Fauber R. Behavioral management of psychogenic cough: alternative to the "bedsheet" and other aversive techniques. Pediatrics 1991;87:532-7.

89. Weinberg EG. "Honking": psychogenic cough tic in children. S Afr Med J 1980;57:198-200.

90. McGarvey LP, Warke TJ, McNiff C, et al. Psychogenic cough in a school boy: evaluation using an ambulatory cough recorder. Pediatr Pulmonol 2003:36:73-5.

91. Wamboldt MZ, Wamboldt FS. Psychiatric aspects of respiratory syndromes. In: Taussig LM, Landau LI, eds. Pediatric respiratory medicine. St Louis: Mosby, 1999:1222-34.

92. Butani L, O'Connell EJ. Functional respiratory disorders. Ann Allergy Asthma Immunol 1997; 79:91-9.

93. von Vigier RO, Mozzettini S, Truttmann AC, et al. Cough is common in children prescribed converting enzyme inhibitors. Nephron 2000;84:98.

94. Bianchetti MG, Caflisch M, Oetliker $\mathrm{OH}$. Cough and converting enzyme inhibitors Eur J Pediatr 1992;151:225-6.

95. Jegoux F, Legent F, Beauvillain de Montreuil C. Chronic cough and ear wax. Lancet 2002;360:618.

96. $\mathbf{0 j o o} \mathbf{J C}$, Kastelik JA, Morice AH. A boy with a disabling cough. Lancet 2003:361:674.

97. Galvez RA, McLoughlin FJ, Levison $\mathrm{H}$. The role of the methacholine challenge in children with chronic cough. J Allergy Clin Immunol 1987;79:331-5.

98. Chang $\mathbf{A B}$, Phelan PD, Carlin J, et al. Randomised controlled trial of inhaled salbutamol and beclomethasone for recurrent cough. Arch Dis Child 1998;79:6-11.

99. Marchant JM, Masters IB, Taylor SM, et al. Evaluation and outcome of young children with chronic cough. Chest 2006;129:1132-41.

100. Somerville M, MacKenzie I, Owen P, et al. Housing and health: does installing heating in their homes improve the health of children with asthma? Public Health 2000;114:434-9. 
101. Baugh JG, Hunter SM, Webber IS, et al. Developmental trends of first cigarette smoking experience of children: the Bogalusa heart study. Am J Public Health 1982; 72:1161-4.

102. Adams $\mathbf{L}$, Lonsdale $\mathrm{D}$, Robinson $\mathrm{M}$, et al. Respiratory impairment induced by smoking in children in secondary schools. BMJ 1984;288:891-5.

103. Charlton A. Children's coughs related to parental smoking. BMJ 1984;288:1647-9.

104. Taussig LM, Smith LM. The chronic bronchitis complex in childhood: what is it? Pediatrics 1981;67:1-5.

105. Morgan WJ, Taussig LM. The chronic bronchitis complex in children. Pediatr Clin North Am 1984;31:851-64.

106. Field CE. Bronchiectasis in childhood: aetiology and pathogenesis including a survey of 272 cases of doubtful irreversible bronchiectasis. Pediatrics 1949;4:231-48.

107. Field CE. Bronchiectasis in childhood: prophylaxis, treatment and progress with a follow up study of 202 cases of established bronchiectasis. Pediatrics 1949;4:35572.

108. Phelan PD, Landau LI, Olinsky A. Epidemiology. In: Respiratory illness in childhood. 4th ed. Oxford: Blackwell Scientific Publications, 1994:27-51.

109. Smith TF, Ireland TA, Zaatari GS, et al. Characteristics of children with endoscopically proven chronic bronchitis. Am J Dis Child 1985;139:1039-10.

110. Dodge R, Burrows B, Lebowitz MD, et al. Antecedent features of children in whom asthma develops during the second decade of life. J Allergy Clin Immunnol 1993;92:744-9.

111. Boule M, Gaultier C, Tournier B, et al. Lung function in children with recurrent bronchitis. Respiration 1979;38:127-34.

112. Seear M, Wensley D. Chronic cough and wheeze in children: do they all have asthma? Eur Respir J 1997:10:342-5.

113. Marchant JM, Morris P, Gaffney JT, et al. Antibiotics for prolonged moist cough in children. Cochrane Database Syst Rev 2005;(4):CD004822.

114. Darelid J, Lofgren S, Malmvall BE. Erythromycin treatment is beneficial for longstanding Moraxella catarrhalis associated cough in children. Scand J Infect Dis 1993;25:323-9
115. Gottfarb P, Brauner A. Children with persistent cough: outcome with treatment and role of Moraxella catarrhalis? Scand J Infect Dis 1994;26:545-51.

116. van Asperen PP, McKay KO, Mellis CM, et al. A multicentre ranomised placebocontrolled double blind study on the efficacy of ketotifen in infants with chronic cough or wheeze. J Paediatr Child Health 1992;28:442-6.

117. Chang $\mathbf{A B}$, Winter $\mathrm{D}$, Acworth JP. Leukotriene receptor antagonist for prolonged non-specific cough in children. Cochrane Database Syst Rev 2006;(2):CD005602.

118. Mehdi N, Weinberger M, Abu-Hasan M. Etiology and outcome of childhood chronic cough using a simple diagnostic approach. Pediatr Asthma Allergy Immunol 2005;18:55-61.

119. Lack G. Pediatric allergic rhinitis and comorbid disorders. J Allergy Clin Immunol 2001;108:S9-15.

120. Campanella SG, Asher MI. Current controversies: sinus disease and the lower airways. Pediatr Pulmonol 2001;31:165-72.

121. Rachelefski GS, Goldberg M, Katz RM, et al. Sinus disease in children with respiratory allergy. J Allergy Clin Immunol 1978;61:310-4.

122. Sacha RF, Tremblay NF, Jacobs RL. Chronic cough, sinusitis and hyperreactive airways in children: an overlooked association. Ann Allergy 1985;54:195-8.

123. Rachelefski GC, Katz RM, Siegal SC. Chronic sinus disease with associated reactive airway disease in children. Pediatrics 1984;73:526-9.

124. Murphy KR. Allergic rhinitis in children: selecting an intranasal corticosteroid Pediatr Asthma Allergy Immunol 2005;18:216-29.

125. Orenstein SR, Orenstein DM. Gastroesophageal reflux and respiratory disease in children. J Pediatr 1988;112:847-58.

126. Malfoot A, Vandenplas $Y$, Verlinden $M$, et al. Gastroesophageal reflux and unexplained chronic lung disease in infants and children. Pediatr Pulmonol 1987:3:208-13.

127. Chang A, Lasserson T, Gaffney J, et al. Gastro-oesophageal reflux treatment for prolonged non-specific cough in children and adults. Cochrane Database Syst Rev 2005;(2):CD004823 